\title{
Monetary Union, Fiscal Crisis and the Pre-emption of Democracy
}

This contribution presents an analysis of the political economy of the European Monetary Union (EMU), focusing on the current fiscal crises in several Member States and proposing an evaluation of the different avenues of crisis management available to policymakers. The EMU has become a systemic cause of macroeconomic destabilisation that Member States find difficult to counteract with their remaining policy instruments. Furthermore, it has greatly increased the vulnerability of some Member States to the repercussions of external shocks, such as the 2007-2009 financial crisis. Efforts of EMU governments to "rescue the Euro" will do little to correct economic imbalances and vulnerabilities, but are likely to deepen economic problems and political alienation in both the rescued and the rescuing polities. This development may yet transform the present economic crisis into a crisis of democratic legitimacy.

Dieser Beitrag analysiert die gegenwärtige Krise der Europäischen Währungsunion (EWU) aus politökonomischer Sicht und untersucht eine Reihe von möglichen Pfaden zur Krisenbewältigung. Die EWU erwies sich in den vergangenen Jahren als Wurzel einer Reihe makroökonomischer Destabilisierungstendenzen, die die Mitgliedstaaten aufgrund der Enge des ihnen verbleibenden Handlungsspielraums vor schwerwiegende Herausforderungen stellen. Zudem nahm in manchen Mitgliedstaaten die Verwundbarkeit gegenüber externen Verwerfungen, wie etwa der Finanzkrise der Jahre 2007-2009, deutlich zu. Schließlich dürfte die „Rettung des Euro“ die grundlegenden Ungleichgewichte kaum ausgleichen, während „Retter" wie „Gerettete“ akuten wirtschaftlichen Problemen und politischen Entfremdungsprozessen gegenüberstehen. Als Folge dieser Entwicklung könnte aus der gegenwärtigen Wirtschaftskrise eine Krise demokratischer Legitimation erwachsen.

\section{Introduction}

In capitalist democracies, governments depend on the confidence of their voters. To maintain this confidence, however, they also depend on the performance of their real economies and, increasingly, on the confidence of financial markets. To meet these requirements at the same time is difficult even under the best of circumstances. At the end of the long period of post-war economic growth, however, theorists of normative political economy postulated the existence of a systemic contradiction between the state's need to ensure democratic legitimacy by 
responding to citizens' demands for public services and redistribution, and the functional requirements of ensuring the continuing profitability of a capitalist economy. Depending on their position on the left-right spectrum of normative orientations, these authors interpreted the expected clash as either a "legitimacy crisis" or as a "governability crisis" of democratic capitalism. ${ }^{1}$

In the following decades, however, neither of these expectations was confirmed. Instead, voters in capitalist democracies seemed to have realised that their wellbeing depended as much on the performance of the capitalist economy as on the public goods, services and transfers provided by the democratic state. Governments were of course held politically accountable for the performance of the public sector and its balance of benefits and compulsory contributions. But they were held equally accountable for managing the capitalist economy and ensuring its continuing provision of jobs, incomes and consumer goods. In effect, the capitalist economy's performance rather than its transformation seems to have become a crucial argument of democratic legitimacy.

This presupposes, however, that democratically accountable governments have the capacity to shape the course of their economies. But compared to the situation in the early 1970s, the progressive internationalisation of economic interactions has greatly increased the difficulties of successful economic management. At that time, liberalisation had been largely confined to product markets. National economic policy needed to ensure international competitiveness under a balance-of-payments constraint - but it was free in the choice of production regimes and in the macroeconomic management of the domestic economy. With the increasing integration of capital markets, however, international capital flows became decoupled from transactions in product markets, and financial interpenetration made national economies vulnerable to crises originating elsewhere. At the same time, international and, even more so, European rules on product and capital market liberalisation imposed legal constraints that eliminated many policy options on which governments had previously relied to manage national economies. Compared to the period before the 1970s, successful economic management has therefore become much harder.

1 Cf., for example, Offe, C.: Strukturprobleme des kapitalistischen Staates, Frankfurt a.M., 1972; Habermas, J.: Legitimationsprobleme im Spätkapitalismus, Frankfurt a.M., 1973; Hennis, W./Graf Kielmansegg, P./Matz, U. (eds.): Regierbarkeit: Studien zu ihrer Problematisierung. Vol. 2, Stuttgart, 1978; Schäfer, A.: Krisentheorien der Demokratie: Unregierbarkeit, Spätkapitalismus und Postdemokratie, in: Der Moderne Staat 2/1 (2009), 159-183; Klenk, T./Nullmeier, F.: Politische Krisentheorien und die Renaissance von Konjunkturprogrammen, in: Der Moderne Staat 3/2 (2010), 273-294. 
In the present essay I focus on the European Monetary Union (EMU), which has removed crucial instruments of macroeconomic management from the control of democratically accountable governments. Worse yet, the EMU has been the systemic cause destabilising macroeconomic imbalances that Member States find difficult or impossible to counteract with their remaining policy instruments. And even though the international financial crisis had its origins beyond Europe, the Monetary Union has greatly increased the vulnerability of some Member States to its repercussions. Its effects have undermined the economic and fiscal viability of some EMU Member States, and have frustrated political demands and expectations to an extent that may yet transform the economic crisis into a crisis of democratic legitimacy. Moreover, present efforts of EMU governments to "rescue the Euro" will do little to correct economic imbalances and vulnerabilities, but are likely to deepen economic problems and political alienation in both the rescued and the rescuing polities.

The paper begins with a brief reflection on the problematic relationship between democratic legitimacy and macroeconomic management, followed by an equally brief restatement of the essential elements of Keynesian and Monetarist policy models and their specific political implications. I then try to show how existing national regimes have been transformed by the creation of the European Monetary Union, and how the destabilising dynamics of the European monetary policy have left some EMU Member States dangerously vulnerable at the onset of the international financial crisis. In the concluding section, I examine the likely politico-economic and political consequences of programs intended to rescue the euro and to reform the regime of the monetary union.

\section{Democratic Legitimacy and Macroeconomic Management.}

After the Great Depression of the 1930s and World War II, governments in Western democracies had rejected "socialist" programs of centralised economic planning but had nevertheless assumed political responsibility for preventing the return of similar economic catastrophes. This was to be achieved through "macroeconomic" policies that would allow the state to increase or reduce aggregate economic demand in order to dampen the ups and downs of economic cycles, to prevent the rise of unemployment or inflation, and to ensure steady economic growth. The belief that macroeconomic management could in fact realise these goals originated in the crisis of the 1930s. It was largely confirmed in the "Keynesian" decades after the War, and it survived the "Monetarist" counter revolution of the 1980s at least in the sense that economic crises continued to be 
seen as consequences of macroeconomic mismanagement. But the very possibility of effective control does then create an internal dilemma of democratic legitimacy - or, more precisely, a potential conflict between the input-oriented and the output-oriented dimensions of democratic legitimacy. ${ }^{2}$

Governments are supposed to carry out the "will of the people" and they are also supposed to serve the "common good". In the input dimension, therefore, governors may be held accountable for policy choices that are in conflict with the politically salient preferences of their constituents, whereas in the output dimension, they may be sanctioned if outcomes that may be attributed to government policy are seen to violate the politically salient concerns of the governed. ${ }^{3}$ In both dimensions, what is initially at stake is political support for the government of the day. But if it appears that elections and changes of government cannot make a difference, the democratic legitimacy of the political regime itself may be undermined.

With regard to macroeconomic management, the outcomes that potentially have very high political salience are rising mass unemployment and accelerating rates of inflation. Since these are not the direct object of policy choices, however, discussions of input legitimacy must focus on the policy instruments that may be employed to affect outcomes indirectly. In macroeconomic economic theory, these include choices in monetary policy, fiscal policy, incomes policy and exchange-rate policy - all of which are assumed to have a direct effect on aggregate economic demand and hence on economic growth, inflation and employment. They differ greatly, however, in their political salience and, hence, in their potential relevance for input-oriented democratic legitimacy.

2 Scharpf, F.W.: Governing in Europe: Effective and Democratic?, Oxford, 1999, chapter 1. The distinction between input- and output-oriented dimensions of democratic legitimacy uses the vocabulary of political systems theory (cf. Easton, D.: A Sytems Analysis of Political Life, New York, 1965), but has its roots in a much older tradition of normative political theory that struggles with the basic tension of having to treat governors, at the same time, as agents and as trustees of the people (cf. Scharpf, F.W.: Demokratietheorie zwischen Utopie und Anpassung, Konstanz, 1970).

3 Salience is a highly contingent and selective attribute of policy issues or outcome conditions that may affect the outcome of elections or incite citizens to engage in political action. And whereas accountability for policy choices can be clearly targeted at a particular government, accountability for outcomes implies a distinction between events and conditions that are thought to be under the potential control of "government", and others which are ascribed to an "act of god". In multi-level polities, moreover, it is often unclear which level of government is causally responsible for which outcomes. But since voters are not obliged to be fair, they will tend to hold those governments accountable over which they happen to have electoral control - which in Europe is true of national governments, rather than European governing institutions. 
Under normal conditions, monetary policy has relatively low salience in the electoral arena. It is seen to involve highly technical decisions that are best left to specialists in central banks and other agencies with an expertise in analyzing and manipulating macroeconomic aggregates. Ultimately, of course, these aggregates will also affect individuals and firms, and they may have massive distributional consequences. But these are not immediately visible, and when they occur, they are not obviously related to specific policy choices. The same is true of policies affecting the exchange rate. Fiscal-policy, by contrast, while also aiming at the public-sector deficit as an aggregate variable, must be implemented through disaggregated taxing and spending decisions that have a direct impact on the incomes of individuals and firms. And the same would be true if governments should (as they tried to do in some countries in the 1970s) adopt incomes policies that impose direct wage controls.

Unlike monetary policy, therefore, choices of fiscal and incomes policy are liable to become politicised. If they should violate the politically salient $e x$-ante preferences of constituencies, they may reduce the electoral support of governments and, in the extreme case, undermine input legitimacy regardless of their functional necessity for achieving acceptable macroeconomic outcomes. In other words, macroeconomic management creates the possibility for a democratic dilemma: By attempting to maintain output legitimacy through functionally effective policy choices, governments may undermine their input legitimacy - and vice versa. In actual practice, however, the intensity of the dilemma depends not only on the type of economic challenges but also on the choice between the Keynesian or Monetarist models or paradigms of macroeconomic management.

\section{Keynesian Problems and the Bundesbank's Monetarist Social Compact}

The Keynesian model assigns the leading function to fiscal policy. In a recession, it is supposed to expand aggregate demand through tax cuts and deficit-financed expenditures; and when the economy is overheating, demand should be reduced through tax increases and spending cuts. Monetary policy is supposed to be "accommodating" - that is to finance fiscal expansion at low interest rates and to avoid a collapse of domestic demand during fiscal retrenchment. Having been conceived in response to the Great Depression of the 1930s, the overriding goal of the Keynesian paradigm was to maintain full employment. In the U.S. and the U.K. it worked reasonably well in combating recessions during the early postwar decades. Even then, however, it was obvious that fiscal retrenchment was politically much more difficult to implement than fiscal expansion - which im- 
plied continuous inflationary pressures and a steady accumulation of publicsector debt.

Moreover, the British experience demonstrated that - under conditions of an industrial-relations system with powerful and competitive unions - an effective incomes policy should have been a necessary complement to fiscal Keynesianism. Without it, expansionary fiscal impulses were quickly consumed by wage increases. Because statutory wage controls did not seem to work, governments tried to contain wage-push inflation through stop-go policies that never allowed steady economic growth to take off. In the "stagflation" period of the 1970s, when the oil price crisis combined the challenges of demand-deficient unemployment and cost-push inflation, the Keynesian model finally failed almost everywhere. Fiscal expansion would have accelerated inflation, and fiscal retrenchment would have driven up mass unemployment - and in fact most countries ended up with both. In a few countries, however, economically sophisticated and organisationally powerful and centralised unions were able to contain cost-push inflation through effective wage restraint, allowing fiscal and monetary reflation to prevent the rise of mass unemployment. ${ }^{4}$

The Monetarist paradigm, which has its theoretical roots in pre-Keynesian neoclassical economics, ${ }^{5}$ owed its practical appeal to the collapse of Keynesian policies in the 1970s. From a political-science perspective, however, its greatest comparative advantage was its lesser dependence on politically salient policy choices. Abandoning the political commitment to full employment, the Monetarist paradigm assigned the leading role to the monetary policy of an independent central bank, whose paramount function is to maintain price stability. Beyond that, it ensures a steady money supply sufficient to allow non-inflationary economic growth. Whether this could be realised in practice then depended entirely on the willingness of governments and unions to adjust their claims on the total economic product to the monetary corridor defined by the central bank.

The German Bundesbank was the first to establish a Monetarist regime in the early 1970s. After having dramatically demonstrated the destructive potential of monetary retrenchment in the crisis of 1973/4, the Bank did in fact confront the government and the unions with the offer of an implicit "social compact". ${ }^{6}$ It

5 Johnson, H.G.: The Keynesian Revolution and the Monetarist Counter Revolution, in: American Economic Review 61/2 (1971), 91-106.

6 Scharpf, F.W., Crisis and Choice, op. cit., 1991, 128-139. 
took great pains to explain to the government, unions, and public, how coordination by monetary policy would not only ensure price stability but also produce economically superior and politically justifiable macroeconomic outcomes. Once rampant inflation was brought under control, it would precisely monitor the state of the German economy and pre-announce annual monetary targets by reference to the current "output gap". Maximum non-inflationary growth would then be achieved if fiscal policy merely were to allow the "automatic stabilisers" to rise and fall over the business cycle, and if wages were to rise with labour productivity. Thus, fiscal policy would be relieved of its heroic Keynesian role, and unions would no longer be pressured to enact a countercyclical incomes policy.

In other words, responsibility for the management of the economy would be assumed by the "non-political" monetary policy of the independent Bank, whereas non-inflationary fiscal and wage policies could be conducted with a low political profile. And as governments and unions did learn to play by the Bank's new rules, the Monetarist regime did in fact work reasonably well, economically and politically, for Germany. ${ }^{7}$

\section{From Monetarism in One Country to Monetary Union}

Originally, Monetarist as well as Keynesian models had been designed for national economies which were exposed to international competition in product markets, but retained control over their monetary regimes. For both, therefore, increasing capital mobility would raise difficulties. Keynesian reflation would become prohibitively expensive if the central bank was no longer able to maintain low interest rates; and monetary policy could not be targeted to the "output gap" of the national economy if interest rates were determined by the fluctuations of international capital markets. This became obvious in the early 1980s, when German recovery was crushed as the Bundesbank found it necessary to follow the dramatic increase of American interest rates, or when fiscal reflation in France had to be aborted under the pressure of massive capital flights. At the same time, capital mobility had also increased the volatility of exchange rates, which was seen as a major problem for exporters in integrated product markets.

7 This is a stylised account that does not apply to conflicts in 1991-92 when the Bank drastically (and from its perspective, successfully) intervened against rising public-sector deficits in the wake of German unification. 
There were several reasons, therefore, for European governments to be interested in creating a common European monetary regime. ${ }^{8}$

The first such attempt, the European "Snake in the Tunnel" of 1972, had quickly disintegrated in the oil-price crisis. Subsequently, the "European Monetary System" (EMS) of 1979 committed its Member States to peg their currencies to a currency basket (the "ECU"). But since Germany was the biggest economy and the most important trading partner for most other Member States, the EMS meant in fact that their currencies were pegged to the Deutschmark - which also implied that in order stay within the agreed-upon bandwidth, their central banks needed to mirror the stability-oriented monetary policy of the Bundesbank. For the other Member States, this turned out to be difficult for several reasons:

First, German monetary policy continued to be precisely targeted to German conditions which could differ from those of the other member economies. Hence when, in 1992, the Bank decided to punish Helmut Kohl for the deficit-financing of German unification, other economies suffered as well - and the U.K. and Sweden (that had only recently joined the EMS) were catapulted out of the Monetary System by currency speculation. Moreover, governments and unions that had not gone through the harrowing German experiences of 1973-75 and 198182 did not necessarily appreciate the awesome power of monetary constraints. Nor had their central banks a background of institutional autonomy, experience and credibility that would have allowed them to intervene with equal authority against public-sector deficits and wage settlements that diverged from the path defined for Germany.

Even more important, however, were the institutional differences in national wage-setting systems. The Monetarist regime worked in Germany because wage leadership was exercised by large and economically sophisticated industrial unions that had learned to operate within the monetary constraints. In contrast, countries with powerful but fragmented and competitive unions and decentralised wage-setting institutions simply did not have the capacity to contain the inflationary pressures of wage competition. ${ }^{9}$

8 It should be noted, however, that the initiatives were coming from Germany. With the breakup of the Bretton-Woods regime, German producers had lost the protection of an undervalued currency, and currency fluctuations were particularly unfavorable for export-oriented investment-goods branches operating with high fixed costs.

9 Baccaro, L./Simoni, M.: Organizational Determinants of Wage Moderation, in: World Politics 62/4 (2010), 594-635. 
As a consequence, inflation rates (Figure 1, cf. Appendix) and unit labour costs (Figure 2) continued to differ; and in order to compensate for losses in international competitiveness, exchange rates and bandwidths were frequently readjusted. As devaluation remained a possibility, the risk premia of government bonds differed considerably among EMS Member States (Figure 3). Moreover, any attempt to defend unrealistic exchange rates would invite currency speculation. $^{10}$

These problems persuaded European governments that moving from the EMS to a monetary union with irrevocably fixed exchange rates would be desirable. It would end their dependence on the Bundesbank, and it would eliminate the possibility of devaluation - and hence both the risk of currency speculation, and the interest-rate differentials caused by the risk of devaluation. Germany in turn, which had much to lose in a monetary union ${ }^{11}$ but was willing to accept it as the political price for German unification, was able to insist that the Bundesbank and its version of Monetarism should become the model for the European system, and that candidate countries would have to meet tough convergence criteria as a condition of admission. ${ }^{12}$

In effect, therefore, the Maastricht Treaty protected the institutional independence of the European Central Bank (ECB) even more firmly than had been the case in Germany. And to ensure its Monetarist orientation, the priority of price stability was specified in the Treaty as well. Moreover, in order to gain access to the Monetary Union, EU Member States had to remove all restrictions on capital mobility, to stabilise their exchange rates to the ECU, and to achieve convergence on low rates of inflation and low public sector deficits.

10 De Grauwe argues that frequent small adjustments had worked well until 1987 , and that it was the attempt to move toward more fixed exchange rates and greater convergence that made the EMS too rigid and then invited large-scale currency speculation; cf. De Grauwe, P.: Economics of Monetary Union, $8^{\text {th }}$ Edition. Oxford, 2009, 137-142.

11 The main loss, as will soon become clear, was the goodness-of-fit of monetary policy. But from the perspective of export-oriented German industries, the pre-Maastricht EMS had also been an ideal arrangement. It was sufficiently effective in dampening currency fluctuations. And it also maintained the Deutschmark as an undervalued currency as other Member States always tried, but never quite succeeded, to match the German passion for stability. This advantage was lost as other countries intensified their efforts to meet the Maastricht criteria on price stability, and as Germany came to adopt the Euro at an overvalued exchange rate.

12 Delors, J.: Report on Economic and Monetary Union in the European Community, Brussels, 1989; McNamara, K.R.: The Currency of Ideas: Monetary Politics in the European Union, Ithaca, 1998; Dyson, K./Featherstone, K.: The Road to Maastricht: Negotiating Economic and Monetary Union, Oxford, 1999; Jones, E.: The Politics of Economic and Monetary Union: Integration and Idiosycracy, Lanham. 2002; Vaubel, R.: The Euro and the German Veto, in: Econ Journal Watch 7/1 (2010), 82-90. 
Perhaps unexpectedly, these "Maastricht criteria" on inflation, deficits, and exchange-rate stability were in fact met by a considerable number of unlikely candidate countries - sometimes through creative accounting, but mainly through heroic efforts at budget consolidation and "social pacts" whose short-term effectiveness was not necessarily sustainable over the longer term. In an attempt to forestall future lapses, Germany therefore also insisted on a "Stability and Growth Pact" that defined permanent limits on national deficits and indebtedness together with seemingly tough sanctioning procedures. ${ }^{13}$

\section{From 1999 to 2007: Monetarism in a Non-optimal Currency Area}

Initially, the Monetary Union did indeed fulfil the hopes of its supporters. The widely resented dominance of the Bundesbank was replaced by a common European Central Bank that targeted its policy choices on average inflation rates and output gaps in the eurozone, rather than on the state of the German economy. National inflation rates that had steeply declined in the run-up to the euro continued to remain significantly lower than they had been in the 1990s (Figure 4) and, most importantly, financial markets honoured the elimination of devaluation risks, so that interest rates on government bonds and commercial credit declined steeply to the German level in all EMU Member States (Figure 3). The result was an initial boost to economic growth in those eurozone economies where interest rates had fallen - which of course was not the case in Germany (Figure 5). Despite the pre-1999 convergence, therefore, Member States entered the EMU in significantly differing economic circumstances.

Such conditions had been discussed earlier under rubric of whether the EMU could be considered an "optimum currency area" - defined by high mobility of capital and labour and the availability of inter-regional transfers to deal with the possibility of "asymmetric shocks". ${ }^{4}$

13 Heipertz, M./Verdun, A.: Ruling Europe: The Politics of the Stability and Growth Pact, Cambridge, 2010.

14 Mundell, R.A.: A Theory of Optimal Currency Areas, in: American Economic Review 51/4 (1961), 657665; McKinnon, R.I.: Optimum Currency Areas, in: American Economic Review 53/4 (1963), 717-725; Eichengreen, B.: Is Europe an Optimum Currency Area?, CEPR Discussion Paper 478, London, 1990; Eichengreen, B./Frieden, J. (eds.): The Political Economy of European Monetary Unification, Boulder, 1994. 
When compared to the United States, these conditions were lacking in Europe. ${ }^{15}$ But given the political commitment to monetary unification, and the encouraging effects of national efforts to meet the Maastricht convergence criteria, optimism prevailed: Considering national public-sector deficits as the main challenge to price stability, and assuming that the Stability Pact would effectively control these, it was expected that the increasing integration of capital and goods markets would also ensure a continuing convergence of prices, wages and business cycles. ${ }^{16}$ As it turned out, however, these expectations were misleading ${ }^{17}$ for two related reasons:

On the one hand, the political crash programs, through which unlikely candidate countries had achieved an impressive convergence on the Maastricht criteria, had generally not addressed the underlying structural and institutional differences that had originally caused economic divergence. Once access was achieved, these differences would reassert themselves. ${ }^{18}$

On the other hand, ECB monetary impulses reflected average economic conditions in the eurozone and hence could not be targeted at the conditions of specific national economies. In effect, therefore, the crucial precondition of Monetarism - a precise fit between money supply and growth potential of a specific economy - would not exist in a heterogeneous monetary union. In other words, the European Central Bank could not be expected to reproduce the Bundesbank's success in Germany. Instead of ensuring steady, inflation-free economic growth in the

15 Lars Jonung and Eoin Drea provide a comprehensive survey of American economic analyses of European monetary integration from 1989 to 2002. They argue that initial skepticism was based on a static interpretation of the optimal currency area that ignored the dynamic impact of currency union on trade and factor mobility, and that a more optimistic view also came to prevail in academic analyses as the success of the Maastricht convergence criteria became apparent. Remarkably, however, none of these contributions seem to have focused on differences in wage-setting systems as a factor affecting the conditions of "optimality", and it appears as if only Milton Friedman was explicitly worried about the effect of unitary monetary policy on divergent member economies (cf. Jonung, L./Drea, E.: It Can't Happen, It's a Bad Idea, It Won't Last: US Economists on the EMU and the Euro, 1989-2002, in: Econ Journal Watch 7/1 (2010), 4-52, esp. 29).

16 Issing, O.: On Macroeconomic Policy Co-ordination in EMU, in: Journal of Common Market Studies 40/2 (2002), 345-358.

17 They were right in predicting that (1) monetary union would increase trade flows and capital flows, and that (2) increasing trade flows under a common currency would tend to equalise the prices of tradable goods and services. There was no reason to think, however, that (3) prices in the non-traded sector would also be equalised. Thus differences in inflation rates could persist even though the euro-level average rate was constrained by ECB monetary policy, and even though differences in consumer prices were reduced by price convergence in the traded sector.

18 Willett, T.D./Permpoon, O./Wihlborg, C.: Endogenous OCA Analysis and the Early Euro Experience, in: The World Economy 33/7 (2010), 851-872. 
member economies of the EMU, the ECB's uniform monetary policy would amplify deviant dynamics in economies above and below the average. ${ }^{19}$

For countries with below-average rates of economic growth and inflation, the uniform ECB interest rates were too high, and the real interest rates faced by domestic consumers and investors were even higher - with the consequence that initially weak economic activity was depressed even further by restrictive monetary impulses. For countries with above-average rates of inflation, by contrast, ECB monetary policy was too loose, nominal interest rates were too low, and real interest rates became extremely low or even negative (Figure 6). Thus, the boost to economic activity that former weak-currency countries had received through the fall of nominal interest to German levels was subsequently intensified and accelerated by ECB monetary policy.

In dealing with the dynamics introduced by mis-specified monetary impulses, the Monetary Union left Member States to their own devices. Since the "nonpolitical" monetary and exchange-rate instruments of macroeconomic management were Europeanised, this meant that governments would again have to resort to those "Keynesian" instruments of fiscal and incomes policy which, because of their much greater political salience, had failed in most countries when they were employed in the 1970s. But this is not the complete story. Like its Keynesian counterpart, Monetarist theory is ostensibly concerned with the management of aggregate economic demand. But unlike Keynesianism, its "micro foundations" are provided by neoclassical micro-economics and its postulate of perfect markets. For its promoters, it therefore seemed plausible to consider problems that might still arise under a Monetarist regime as the consequence of imperfectly flexible product and labour markets. In practice, therefore, demand-oriented Monetarist macroeconomics was typically associated with a panoply of "supplyside" policy recommendations, including tax cuts, privatisation, liberalisation, deregulation and, if need be, union busting (all of which had been part of Margaret Thatcher's and Ronald Reagan's Monetarist programs). There is no question, however, that the use of these instruments would also have very high political salience in EMU member polities.

19 Sinn, H.W./Widgrén, M./Köthenbürger, M. (eds.): European Monetary Integration, Cambridge (M.A.), 2004; Enderlein, H.: Nationale Wirtschaftspolitik in der europäischen Währungsunion, Frankfurt a.M., 2004. 


\section{Germany: The Sick Man of Europe Rescued by Union Wage Restraint}

The first victim of mis-specified monetary impulses was Germany. ${ }^{20}$ Before 1999, not only nominal interest rates, but also real interest rates had been lowest in Germany. With entry into the Monetary Union, however, these comparative advantages were lost. Since nominal interest rates converged whereas German inflation rates continued to be lower, real interest rates in Germany became the highest in the eurozone (Figure 6). As a consequence, economic growth was lower in Germany than in almost all EMU member economies (Figure 5), unemployment increased dramatically from 2000 to 2005 (Figure 7), as did social expenditures, whereas tax revenues fell by 2.4 percentage points from 2000 to 2004.

In responding to this deep recession, Germany could not rely on any one of the instruments of macroeconomic management. Where the Bundesbank would have lowered interest rates in response to the rapidly increasing output gap, ECB interest rates were causing the problem. And where an autonomous government would have resorted to fiscal reflation, Germany came to violate the 3-percent deficit limit of the Stability Pact by merely allowing the "automatic stabilisers" to operate. And as monetary as well as fiscal reflation was ruled out, incomes policy also could not be employed as an instrument for demand expansion. Even if unions, in the face of rising mass unemployment, had been able to achieve wage increases exceeding productivity gains plus inflation, the positive effect on domestic demand would have been overshadowed by job losses due to reduced profitability and falling export demand.

Instead, Germany's large industrial unions in the export sectors decided to protect existing jobs through wage restraint - a supply-side strategy that allowed employers to capture most of the productivity gains in the hope of stabilising employment by improving the profitability of domestic production and the competitiveness of German industries in international markets. ${ }^{21}$ At the same time, however, stagnant or falling real wages (Figure 8) would further reduce domestic demand and keep inflation below the EMU average - with negative effects on

20 Spethmann, D./Steiger, O.: Deutschlands Wirtschaft, seine Schulden und die Unzulänglichkeiten der einheitlichen Geldpolitik im Eurosystem, in: Detlev Ehrig/Uwe Staroske (eds.): Dimensionen angewandter Wirtschaftsforschung: Methoden, Regionen, Sektoren. Festschrift für Heinz Schäfer zum 65. Geburtstag, Hamburg, 2005, 255-285.

21 In real terms, German unions helped to re-establish the advantages of an undervalued currency - providing the functional equivalents of export subsidies and import duties in ways which could not be challenged under the EU's competition and internal-market rules. 
domestic economic growth and on imports. And the Red-Green government on its part, bereft of all demand-side policy options, was also pushed toward supplyside policies. Between 2000 and 2005, the government managed to reduce taxes on company profits and capital incomes, to lower the level of employment protection, primarily by deregulating temporary and part-time employment (Figure 9), and to drastically cut benefits to the long-term unemployed in order to reduce the reservation wage of job seekers. ${ }^{22}$ There is no question that these policies were not only highly salient but also extremely unpopular, especially with the supporters of the social-democratic governing party. Mass demonstrations against the welfare reforms and the rise of a left-wing protest party brought about the defeat of the Red-Green government in the 2005 elections. Apart from this change in partisan fortunes, there is also a significant decline of lower-class electoral participation - which does indeed suggest a more serious erosion of political legitimacy. ${ }^{23}$

Economically, however, the combination of extreme wage restraint practiced by German unions and the government's supply-side policies achieved its desired effect. Export demand and, eventually, employment in the export industries and in a growing low-wage sector increased, and registered unemployment began to decline after 2005 (Figure 7). In effect, Germany, which had been the "sick man of Europe" between 2000 and 2005, managed to pull itself out of the long recession to become once more one of the strongest European economies at the onset of the international financial crisis in 2007.

In an integrated economic environment, however, successful supply-side policies which reduce the cost and increase the profitability of domestic production in one country must inevitably have the effect of beggar-my-neighbour strategies on its competitors. ${ }^{24}$ In the process of coping with its own crisis, therefore, Germany also contributed to the economic vulnerability of other eurozone economies, and to the increasing current-account imbalances among these economies (Figure 10). ${ }^{25}$

22 Trampusch, Chr.: Der erschöpfte Sozialstaat: Transformation eines Politikfeldes, Frankfurt a.M., 2009.

23 Schäfer, A.: Consequences of Social Inequality for Democracy in Western Europe, in: Zeitschrift für vergleichenden Politikwissenschaft, 4 (2010).

24 De Grauwe, P., Economics, op. cit., 2009; Flassbeck, H.: Die Marktwirtschaft des 21. Jahrhunderts, Frankfurt a.M., 2010.

25 The link is established by a combination of three different mechanisms: By cutting costs and constraining domestic demand, Germany increased exports and reduced imports in relation to the rest of the world. Since revenues from the export surplus were not fully consumed or invested in Germany, they were available for investment and credit in those economies where, for reasons to be discussed below, 


\section{The Rise and Increasing Vulnerability of GIPS Economies}

In the former soft-currency countries - I will look at Greece, Ireland, Portugal and Spain, labelling them GIPS economies - accession to the EMU had the initial effect of interest rates falling to much lower German levels. The sudden availability of cheap capital, whose domestic attractiveness was further increased by near-zero or even negative real interest rates, fuelled credit-financed domestic demand in Greece, Ireland and Spain (though less so in Portugal, for reasons that I have not been able to explore). In Spain and Ireland, in particular, cheap credit came to finance real-estate investments and rapidly rising housing prices which, eventually, would turn into bubbles. As a consequence, economic growth (Figure 5), employment (Figure 11), per-capita incomes (Figure 12) and prices (Figure 4) continued to increase. At the same time, real wages (Figure 8) and unit labour costs (Figure 13) also increased. ${ }^{26}$ As a consequence, imports would rise, export competitiveness would suffer and deficits of current accounts would increase (Figure 10).

Even if they had considered the decline of their external balances a serious problem, however, the governments in GIPS economies found no effective way to counteract domestic booms that were driven by the cheap-money effect of uniform ECB interest rates. Spain and Ireland at least tried to achieve some restraint through the instruments of macroeconomic policy that were still available nationally. But their attempts to contain wage inflation through a series of social pacts and to practice fiscal constraint by running budget surpluses (Figure 15) proved insufficient. ${ }^{27}$ What could have made a difference was monetary restraint, which would have impeded the credit-financed overheating of the Greek, Irish and Spanish economies. This, however, would have required differentiated, ra-

demand for consumer and investment credit was particularly high. In effect therefore, German capital exports came to finance rising imports and increasing indebtedness in recipient economies.

26 The mechanism is complex: The initial fall of interest rates facilitated the rise of credit-financed consumer and investment demand. In the traded sector, imports would rise, prices would be constrained, and employment might fall. In the non-traded sector, however, increasing demand would raise domestic production and employment and create room for wage increases. Whether it will be exploited depends on national wage-setting institutions. In Sweden and Austria, centralised wage bargaining was generally able to prevent increases that would hurt international competitiveness in the traded sector. In Germany, the same effect is traditionally achieved by the wage leadership of the big industrial unions. But where such institutions do not exist, union competition and egalitarian norms of "comparability" will favor the diffusion of wage increases achieved in branches with the greatest ability to pay, or the least ability to resist (cf. Scharpf, F.W., Crisis and Choice, op. cit., 1991; Baccaro, L./Simoni, M., op. cit., 2010). In the traded sector, therefore, wages may rise even as employment is shrinking.

27 Baccaro, L./Simoni, M., op. cit., 2010. 
ther than uniform, monetary policies that would not be defined by eurozone averages but targeted to the specific conditions and problems of the individual economies. ${ }^{28}$ Such approaches, ${ }^{29}$ however, played no role in the construction of either the European Monetary Union or of the Stability Pact, ${ }^{30}$ nor were they considered by mainstream monetary economics prior to the present crisis. ${ }^{31} \mathrm{Un}$ der the dominant view, the ECB was responsible only for average price stability in the eurozone as a whole, whereas all adjustment problems of individual economies were to be dealt with by EMU Member States.

At the onset of the financial crisis, the GIPS economies therefore found themselves in extremely vulnerable positions defined by severe current-account deficits, an extreme dependence on capital inflows and severely overvalued real exchange rates. For countries with independent currencies (unless that currency was the U.S. Dollar), this process could not have continued for long. Under fixed exchange rates, it would be stopped by a balance-of-payments crisis, and under flexible rates, devaluation would raise the price of imports and restore the competitiveness of exports. In the Monetary Union, however, external constraints were eliminated. Foreign investors and creditors were no longer concerned about currency risks, and banks in countries such as Germany were happy to re-invest export incomes in bonds and asset-based securities issued by Greek, Spanish or Irish banks. Hence the rapidly increasing deficits of current accounts were not corrected, but financed through equally increasing capital flows from surplus to

28 De Grauwe (Economics, op. cit., 2009, 177-182) shows how the higher interest rates required (under the "Taylor rule") for high growth economies such as Ireland, Greece or Spain would be systematically outvoted in the ECB Governing Council under the influence of the ECB Board whose members are assumed to target average eurozone conditions.

29 In the history of economic theory, the need for and the feasibility of differentiated solutions had been postulated by the renowned Swedish economist Erik Lindahl (cf. Lindahl, E.: Penningpolitikens Medel (The Means of Monetary Policy), Lund, 1930). In his view, the central bank of a monetary union of independent states would need to correct diverging business cycles and inflation rates in member economies by differentiating the supply of central-bank money that national central banks could offer to national banks - which would in turn lead to nationally differing interest rates. It has recently been argued, albeit by heterodox economists, that such options could also be realised in the EMU (Spethmann, D./Steiger, O., op. cit., 2005).

30 Heiperts, M./Verdun, A., op. cit., 2010.

31 De Grauwe, P., Economics, op. cit, 2009; De Grauwe, P.: The Governance of a Fragile Eurozone, University of Leuven, 2011. One would of course need to know whether, under present conditions of high capital mobility, the effect of differentiated monetary policies would be immediately wiped out by arbitrage, or whether some forms of capital controls could be designed to ensure their effectiveness. Moreover, one would have to explore the political and intra-institutional implications for ECB monetary policy if it were to become responsible for explicitly discriminating measures addressed to individual member economies. 
deficit economies in the eurozone (Figure 14). By the same token, of course, real effective exchange rates diverged as well, with Germany benefitting from an increasingly undervalued currency, and GIPS economies suffering from overvaluation (Figure 17).

What eventually mattered most was the increasing dependence on capital inflows and the rise of external - and mainly private ${ }^{32}$ - indebtedness, which left GIPS economies extremely vulnerable to disturbances in international financial markets that might provoke capital flight. ${ }^{33}$ Hence, even if the toughened version of the Stability Pact that is presently being enacted had been in place in 2007, it would have done little to reduce the economic vulnerability of the GIPS economies. In any event, however, under the rules of the Monetary Union that were then in place, neither rising current-accounts deficits nor the increasing dependence of GIPS economies on capital imports and divergent real exchange rates were treated as problems that might require intervention by either the Commission or the European Central Bank.

The Stability Pact was supposed to deal only with excessive budget deficits (Figure 15) and, what is even more important, it did not differentiate between deficits incurred in a recession or in high-growth periods. Thus after Germany (with the support of France) had successfully resisted punishment for operating automatic stabilisers during its deep recession between 2000 and 2005, it would have been politically difficult to prosecute high-growth Greece (even if its deficit had been correctly reported). But while the Stability Pact could and should have been invoked against Greece, it was simply irrelevant for Spain and Ireland. Compared to Germany, their governments were models of fiscal probity, running budget surpluses in most years up to 2007, and reducing total public-sector debt far below the official target of 60 percent of GDP (Figure 16). Even though, in the absence of monetary restraint, sound macroeconomic management might have required even more aggressive fiscal retrenchment, there was nothing in the

32 In contrast to the currently popular narratives, external indebtedness even in Greece and Portugal was mainly, and in Spain and Ireland exclusively due to private-sector rather than public-sector borrowing. Thus in 2007, the year prior to the financial crisis, the Greece's external balance had amounted to $-14.67 \%$ of GDP, to which public-sector borrowing contributed only $-5.3 \%$. The respective figures for Portugal were $-9.78 \%$ and $-2.65 \%$. In Spain $(-10.02 \%$ and $+1.09 \%)$ and Ireland $(-5.34 \%$ and $+0.14 \%)$, public sector surpluses had actually reduced the external imbalance (Eurostat data).

33 Excessive external indebtedness caused by capital inflows did, of course, also occur in countries with their own currency whose central bank had stimulated the demand for credit through low interest rates. But in that case, a sudden capital flight would produce devaluation, rather than a liquidity and solvency crisis (cf. De Grauwe, P., Governance, op. cit., 2011). 
Stability Pact to suggest to governments that this might be a European requirement.

At the same time, the ECB also saw no reason for alarm as average eurozone inflation rates remained within the limits to which its monetary policy was committed. And while all GIPS economies had higher rates than Germany, these were not exorbitantly higher and seemed not to accelerate (Figure 4). This may appear surprising since the bursting of credit-financed real-estate bubbles in Ireland and Spain is now seen as a major cause of the present crisis in these countries. But technically, escalating real-estate and housing prices are defined as "asset price inflation" which the ECB, like other central banks, will only take into account when its "wealth effect" is expected to also affect the rise of consumer prices. ${ }^{34}$ Furthermore, the rise of consumer prices in GIPS economies continued to be constrained by lower-priced imports.

\section{Summary: The Eurozone on the Eve of the Crisis}

By 2007, conditions in the eurozone could therefore be described as follows: the Monetary Union had achieved its proximate political purposes by eliminating currency fluctuations and interest-rate differentials among its member economies. At the same time, however, it had deprived member governments of the monetary and exchange-rate instruments of macroeconomic management and it had tried, through the Stability Pact, to also constrain their employment of fiscal instruments. But since the eurozone was not an "optimal currency area", the imposition of one-size-fits-all ECB interest rates produced "asymmetric" impulses in EMU economies, with above-average or below-average rates of growth and inflation. In low-growth Germany, high real interest rates had deepened and prolonged a recession which, since monetary as well as fiscal reflation were ruled out, was eventually overcome through wage restraint and supply-side "reforms" that constrained domestic demand and increased export competitiveness. In GIPS economies, by contrast, very low real interest rates had fuelled creditfinanced economic growth and employment, but also rapid increases in unit

34 Trichet, J.-C.: Asset Price Bubbles and Monetary Policy. Lecture by the President of the European Central Bank at the Monetary Authority of Singapore, 08.06.2005; De Grauwe, P., Economics, op. cit., 2009, 207-209. With hindsight, it seems obvious that the Irish and Spanish (or American and British) governments could have halted their real-estate bubbles through legislation tightening the availability of housing credit. But if even central-bank economists see no way to distinguish between price increases determined by "rational markets" and "speculative" excesses, it would have taken a good deal of political courage for governments to "stop the party" on grounds of old-fashioned paternalism. 
labour costs that reduced export competitiveness. The resulting rise of currentaccount deficits was accommodated by equally rising capital inflows from investors in surplus economies leading to rising external debts accumulated primarily or exclusively in the private sector. As a consequence, GIPS economies were becoming extremely vulnerable to potential disturbances in international financial markets that might induce capital flight - followed by potential liquidity and solvency crises.

Governments in GIPS countries may have been as unconcerned as the American or British governments about the rise of these imbalances. But even where they tried to constrain their overheating economies, through fiscal retrenchment and attempts at wage moderation, the instruments of macroeconomic policy that were still available to national governments proved insufficient to neutralise the expansionary effects of EMU monetary impulses. At the same time, the escalating economic imbalances and vulnerabilities were also of no concern to EMU policy makers, neither for the Commission enforcing the Stability Pact nor for the ECB carrying out its mandate to ensure price stability.

\section{From 2008 to 2010: A Sequence of Three Crises}

The question as to how long the external imbalances in the eurozone could have continued, and whether they could have been gradually corrected by market forces or would soon have ended in a crash, has become academic. In the real world, the international financial crisis of 2008 triggered chain reactions which, in the eurozone, had the effect of transforming the vulnerability of deficit countries into a systemic crisis that is thought to challenge the viability of the Monetary Union itself. The much-researched story is far too complex to be retold here in any detail, but for present purposes a thumb-nail sketch of three distinct, but causally connected crises will suffice. ${ }^{35}$

Initially, the direct impact of the American "subprime mortgage crisis" and the Lehman bankruptcy was limited to European countries that had allowed their banks to invest heavily in "toxic" American securities. Apart from the UK, the main victims were Germany and Ireland, whereas banking regulations in Spain had effectively prevented Spanish banks from engaging in off-balance activities abroad. As a consequence, the budget deficits of countries that had to rescue

35 Jones, E.: The Euro and the Financial Crisis, in: Survival 51/2 (2009), 41-54. 
"system-relevant" private or public banks, escalated to previously unheard-of levels (Figure 15).

The secondary impact of the international financial crisis was a dramatic credit squeeze on the real economy as banks had to write off insecure assets on their balance sheets while mutual distrust brought interbank lending to a halt. As a consequence, economic activity declined and unemployment increased in those countries immediately affected by the banking crisis, with these effects spreading quickly to other closely-linked economies. In addition to the fiscal effects of bank bailouts, governments therefore had to accept a steep decline in tax revenues and an equally steep rise in expenditures on unemployment and on the protection of existing jobs. Obviously, however, the effects of the credit squeeze hit hardest those countries whose economic activity had come to depend most on the availability of cheap credit and massive capital inflows- which in the eurozone was the case for GIPS economies. In Ireland and Spain, moreover, the real-estate bubble had burst under the impact of the recession, and mortgage defaults created a secondary banking crisis in which governments had to rescue even more financial institutions (or their creditors in financial institutions of surplus economies). The result was an even more dramatic rise of public-sector deficits and debt ratios even in countries such as Spain and Ireland whose indebtedness had been far below the eurozone average (Figure 16).

In the process, thirdly (and belatedly), international rating agencies and investors ceased to be satisfied with the elimination of currency risks and finally began to worry about the sustainability of public-sector indebtedness - in particular for those countries whose current-account deficits suggested economic weaknesses that might also affect the government's capacity to meet financial commitments. As this happened, the price of outstanding bonds declined, refinancing as well as the placement of new issues became difficult, and the convergence of nominal interest rates to German levels came to an end. As a consequence, after 2008, risk premia on sovereign debt rose to very high and practically prohibitive levels (Figure 18).

The spectre of "sovereign default" arose first in Greece. There, the incoming Pasok government had to admit that public sector deficits (which had significantly violated the Stability Pact even during the high-growth years following accession to the eurozone in 2001) had in fact been grossly under-reported by its predecessors. Confronted with the potential repercussions of Greek bankruptcy on their own banks, and with speculative attacks on other EMU Member States, capital-exporting countries agreed to create a common "Stability Mechanism" 
that would ensure Greek government obligations - this was soon followed by the much larger European Financial Stability Fund (EFSF) whose guarantees were first invoked by Ireland and now also by Portugal. In each case, governments had to accept extremely tough commitments to fiscal retrenchment and supply-side policy reforms - which are now becoming the model for a general regime of fiscal supervision and control in the eurozone.

\section{Beyond the Rescue Operations: Options for a Viable EMU?}

The commitment to create a rescue fund must be understood in the light of its perceived alternative: if GIPS states had gone bankrupt they could have left the Monetary Union and returned to their former national currencies at an exchange rate that corrected the real effective over-valuation. In theory, this would have reestablished the international viability of their economies. But domestically, the transition would have been very painful, and its technical difficulties were perceived as being so overwhelming ${ }^{36}$ that no practical solutions in that direction were even tentatively considered. At the same time, the European Commission, the ECB and the governments of surplus countries also rejected the "bankruptcycum-devaluation" scenario for reasons of their own which, not necessarily in the order importance, could be listed as follows: (1) if GIPS states left the EMU, it would be perceived as a major setback for European integration; (2) it would encourage speculative attacks on other EMU Member States; (3) bankruptcies of GIPS states would entail heavy losses for banks in surplus countries and for the ECB; and (4) the expected revaluation of the euro would hurt export industries in Germany and other surplus economies that benefited from an undervalued real exchange rate. Given these beliefs, expensive guarantees and credits appeared as a lesser evil that was necessary to keep GIPS countries within the Monetary Union (and, perhaps, to provide a push for European solidarity and political integration).

36 As George Selgin put it: "In effect, the authorities kicked away the ladder Europe's economies had scaled to establish a common currency, leaving Europeans with no equally convenient way of retreating to the status quo." Thus, American economists who had warned against creating the EMU were now convinced that the exit option was effectively foreclosed. Cf. Selgin, G.: The Secret of the Euro's Success, in: Econ Journal Watch 7/1 (2010), 78-81; Eichengreen, B., op. cit, 1990; Eichengreen, B.: The Euro: Love It or Leave It?, NBER Working Paper 13393, 2010. 


\section{The Rescue-cum-Retrenchment Program}

The immediate goal of the rescue programs was to avoid bankruptcy by providing access to credit at rates that did not include exorbitant risk premia. This goal is being pursued through a combination of guarantees, ECB open market operations $^{37}$ and direct loans provided by the IMF, and by the stability funds set up by the EU (EFSM) and by the EMU Member States (EFSF). As a consequence, Greece, Ireland and now Portugal have so far been able to avoid insolvency. By themselves, however, the guarantees and credits can only buy time. In order to ensure that governments will be able to restore the confidence of financial markets, they are coupled with stringent "conditionalities" which are meant to reduce the short-term need for credit through rigorous fiscal retrenchment. At the same time, moreover, the conditions imposed are meant to facilitate economic recovery and to restore the international viability of the economies in question.

Thus, the Commission's "Economic Adjustment Programme for Greece" of May 2010 postulated two goals to be pursued over the coming years:

"The immediate priority is to contain the government's financing needs and reassure markets of the determination of authorities to do whatever it takes to secure mediumand long-term fiscal sustainability. (...)

In parallel with short-term anti-crisis fiscal measures, there is a need to prepare and implement an ambitious structural reform agenda to strengthen external competitiveness, accelerate reallocation of resources from the non-tradable to the tradable sector, and foster growth." 38

The Program accordingly included immediate increases of VAT and excise taxes, cuts to public-sector wages, pensions, social expenditures and public investments, and would continue from 2011-2014 with a long list of further tax increases and expenditure cutbacks. The structural reforms to which the government had to commit itself included "the implementation of an ambitious pension reform", reforms of the budgeting and tax systems and of public administration, plus "ambitious labour and product market reforms."

Even though some of these commitments might have appeared somewhat vague, they were specified in much greater detail and continuously tightened by a "Memorandum of Understanding on Specific Economic Policy Conditionality" and its quarterly "updates". These are used to assess progress achieved, to extend

37 Sinn, H.-W.: Die riskante Kreditersatzpolitik der EZB, in: FAZ, 04.05.2011, 10.

38 European Commission: The Economic Adjustment Programme for Greece, Directorate-General for Economic and Financial Affairs, Occasional Papers 61, Brussels, 2010, 10/90. 
the range of required structural reforms and to specify concrete requirements to be met in the following periods. ${ }^{39}$ These Memoranda cut ever more deeply into details of national legislation. ${ }^{40}$ And the opening paragraphs of the Greek and Irish Memoranda and of all subsequent updates leave no doubt as to who is in control of these "understandings":

"The quarterly disbursements of bilateral financial assistance ... are subject to quarterly reviews of conditionality for the duration of the arrangement. The release of the tranches will be based on observance of quantitative performance criteria and a positive evaluation of progress made with respect to policy criteria in ... this memorandum. (...)

The authorities commit to consult with the European Commission, the ECB and the IMF on the adoption of policies that are not consistent with this Memorandum. They will also provide the European Commission, the ECB and the IMF with all information requested that is available to monitor progress during programme implementation and to track the economic and financial situation. Prior to the release of the instalments, the authorities shall provide a compliance report on the fulfilment of the conditionality."

In other words, once an EMU Member State has applied for the protection of European rescue funds, its government will be operating under a form of "receivership". ${ }^{42}$ European and IMF authorities define the criteria to be treated as "conditionality"; the Commission analyzes financial and economic problems, defines the policy choices that are required, monitors compliance and evaluates progress or failure. Of course it prefers to do this in consultation with national authorities and expertise. But in cases of disagreement, the bargaining power of the national government will be minimal - except that it might still threaten to

39 Exactly the same approach has been used in the "Economic Adjustment Programme for Ireland" published in February 2011, and there is no reason to think that it will not also be used for Portugal; cf. European Commission: The Economic Adjustment Programme for Ireland, Directorate-General for Economic and Financial Affairs, Occasional Papers 76, 2011.

40 To illustrate this in the Greek case, the "second update" of 22 November 2010 contained a commitment to "comprehensive reform of the health care system" which in the "third update" of 23 February 2011 came to include detailed targets for the pricing of generics and for the methods by which social security funds pay physicians. Similarly, where the original agreement had contained a commitment to "ambitious labour market reforms", the second update specified a new law allowing firm-level collective agreements to prevail over sector and occupational agreements, and the third update committed the government to "simplify the procedure for the creation of firm-level trade unions". In the Irish case, the "Memorandum of Understanding" of 8 December 2010 was more detailed on reforms of the banking system but also included precise commitments on labour market and pension reforms, on cuts in publicsector employment and pay, on cuts in social programs and reductions of the statutory minimum wage.

41 Quoted from the Irish Memorandum of 3 December 2010.

42 In a recent blog post by Max Keiser, a British TV presenter and former Wall Street broker, the Greek situation is equated with an occupation regime imposed by the "Troika" of EU, ECB and IMF authorities, cf.<www.maxkeiser.com >, 28 April 2011. 
commit political suicide or to reconsider the "bankruptcy-cum-devaluation" option.

It appears doubtful whether the policies imposed by these "rescue-cumretrenchment" regimes, assuming that they would be faithfully implemented, will have a chance of succeeding economically over the medium term. The short-term results, at any rate, do not look promising: total debt burdens are still increasing (Figure 16), and the interest rates for government bonds still seem to be on the rise (Figure 19). At the same time, GIPS economies continue to be in a deep recession, with negative or near-zero rates of economic growth in 2010 and 2011, and with unemployment rates of 15 percent in 2011 in Greece, 14 percent in Ireland, 11-12 percent in Portugal and 20 percent in Spain ${ }^{43}$ (Figure 20). In order to meet their minimal political responsibilities, therefore, governments must deal with high and rising expenditures on unemployment and welfare benefits and they must cope with falling, rather than rising tax revenues - with the implication that despite current denials a severe "restructuring" of existing debt may become unavoidable.

\section{Political Implications}

In purely economic terms, therefore, the immediate outcomes of the "rescuecum-retrenchment" program will not differ greatly from those anticipated in the "bankruptcy-cum-devaluation" scenario. In both cases, creditors should not expect full repayment, and in both cases, international economic viability can only be re-achieved by wage decreases in the traded sector to correct the gap in real effective exchange rates (Figure 17). But the political implications and distributional consequences would be quite different.

"Bankruptcy-cum-devaluation" would be experienced as a sudden shock hitting the country as a whole and which, by dramatically increasing the price of imports, would reduce all domestic real incomes at the same time. Beyond that, however, all cruelties would have been inflicted by the devaluation itself, and national policy and politics could then be about damage control, burden sharing and reconstruction.

The opposite is true under the "rescue-cum-retrenchment" program that is presently being enacted. Here, all cruelties must be proposed, defended, adopted and implemented over an extended period by the national government. In fact, the 
program amounts to a greatly radicalised version of the supply-side reforms adopted in Germany during its (much milder) recession before 2005 - which destroyed political support for Schröder's Red-Green government. But whereas Schröder had the chance of developing and defending self-chosen reforms, the governments of Greece, Ireland and Portugal must implement policies likely to be seen as dictates from Commission bureaucrats and self-interested foreign governments trying to protect their own banks, investors and export industries.

If these are extremely difficult political conditions, they will be exacerbated by the distributional implications. In both scenarios it is clear that the non-traded sector will lose out, and that export-oriented industries and services ought to gain. Beyond that, however, the higher profitability for investments in exportoriented production will have been achieved by the devaluation itself, whereas in the "rescue-cum-retrenchment" program it must be created by governments adopting and implementing policies that must massively and visibly hurt workers and welfare recipients while favouring profits and capital owners. As was the case in Germany, the inevitable result will be a rise in social inequality ${ }^{44}$ and social protest. From the political perspective of GIPS governments, therefore, "bankruptcy-cum-devaluation" may indeed now appear as the lesser of two evils.

\section{From Rescue Operations to EMU Reform}

But the fate of the economies and governments of GIPS countries is only part of a larger process of EMU reforms that are presently under way. In this regard, it is indeed unfortunate that worries about the euro were triggered by the Greek solvency crisis - which was initially seen as the self-inflicted result of fiscal profligacy: if Greek governments had not engaged in reckless borrowing, ${ }^{45}$ it is now widely argued, the euro crisis would not have arisen, and if the Commission had not been duped by faked records, rigorous enforcement of the Stability Pact would have prevented it. So even though the more "virtuous" Member States are now unable to refuse help to the "sinners", such conditions should never be allowed to reoccur. And even though this explanation of the problem is only partly correct for Greece, and totally wrong for Ireland and Spain, it still dominates

44 In fact, Germany was one of the OECD countries where social inequality increased the most between the mid 1990s and the mid 2000s - whereas inequality had decreased in Greece, Spain and Ireland (cf. OECD: Growing Unequal? Income Distribution and Poverty in OECD Countries, Paris, 2008).

45 A major factor seems to have been a particularly pronounced inability or unwillingness to collect taxes. According to OECD figures, Greek tax revenue declined from 37.8 percent of GDP in 2000 to 32.6 percent in 2008 . 
debate about the crisis in the "rescuer" countries, and it frames the approach to reforming the EMU regime.

The "Excessive Deficit Procedure" (EDP), that is to be put into place under Article 126 TFEU, amounts to a tougher version of the Stability Pact - with greater emphasis on the rapid and continuous reduction of total public-sector debt, on the preventive supervision of national budgeting processes, on earlier interventions and sanctions and "reverse majority" rules for the adoption of more severe sanctions by the Council. ${ }^{46}$ But at least the Commission seems also to have realised that budgetary discipline alone, no matter how rigidly enforced, would not have prevented the crises in Ireland and Spain - where the steep rise in publicsector deficits was clearly a consequence, rather than a cause, of the financial and economic crisis.

Hence the Commission now also considers "macroeconomic imbalances" as proximate causes of the present crises, and it has proposed to strengthen the Treaty commitment to coordinated economic policy (Art. $121 \mathrm{TFEU}$ ) by an "Excessive Imbalance Procedure". 47 Its focus will be on current account balances, unit labour costs, real effective exchange rates, total (public and private) indebtedness and other potentially critical aspects of national economic performance. Its central instrument will be a "scoreboard" with a limited (but expandable) list of performance indicators, complete with upper and lower "alert thresholds". On this basis, "complemented by economic judgment and national expertise", the Commission will then identify Member States "deemed at risk of imbalance", followed by "country-specific in-depth reviews", "preventive recommendations" and in the event of "excessive imbalances", Council recommendations of corrective action, with deadlines attached and with compliance to be monitored by the Commission. If governments fail to comply, the Commission

46 European Commission: Proposal for a Regulation of the European Parliament and of the Council on the Effective Enforcement of Budgetary Surveillance in the Euro Area, Nr. 524, 29.09.2010, Brussels, 2010. At the same time, however, the proposed Regulation (7843/11) seems to soften some of the rigidities of the original Stability Pact by relating its deficit rules to the "medium-term rate of potential GDP growth" - this obviously places lots of trust in the reliability of economic forecasts or gives lots of room for discretionary judgments by the Commission.

47 European Commission: Proposal for a Regulation of the European Parliament and of the Council on Enforcement Measures to Correct Excessive Macroeconomic Imbalances in the Euro Area, Nr. 525, 29.09.2010, Brussels, 2010. 
may again propose fines that the Council can only oppose through qualified majority vote. $^{48}$

This ambitious program, which had the support of the Van-Rompuy Committee, was approved by the ECOFIN Council on 15 March $2011,{ }^{49}$ and is to be adopted in June through a series of regulations. It appears remarkable for a number of reasons. First, it replaces the rule-based approach of the Maastricht Treaty and the original Stability Pact with a highly discretionary regime of supranational economic management. Even the new EDP will now refer to projections of "potential growth" for its assessment of national budgets. And the EIP must depend on disputable hypotheses regarding the causal relevance of specific indicators and the critical significance of upper and lower thresholds (quite apart from the politically unresolved issue of whether symmetrical controls should be imposed on surplus and deficit economies). Moreover, practically all the indicators discussed refer to phenomena which, unlike public-sector budgets, are not under the direct control of national governments. Because government capacity to exercise indirect influence over such variables as nominal wages, private saving and spending, consumer credit, etc. may either be non-existent or widely varying among Member States, compliance with the "recommendations" issued by the Commission may well be impossible.

\section{The Worst of Three Worlds}

Remarkably, moreover, there is no acknowledgment in any of the supporting documents of the role that uniform ECB interest rates played in causing macroeconomic imbalances among the heterogeneous member economies of a "nonoptimal currency area". Nor is there any recognition of the ECB's reluctant but constructive role in supporting GIPS banks after 2008, or any discussion on how ECB monetary policy could, in the future, avoid monetary impulses that have the effect of generating imbalances among EMU economies. ${ }^{50}$ In other words, EMU Member States cannot expect any help from the European level in managing

48 In none of the legislative proposals, neither the EDP nor the EIP, is there any suggestion that the adoption of "reverse majority" rules might require Treaty amendments. But cf. Daniel Hannan's blog post dated 04.10 .2010 on $<$ http://blogs.telegraph.co.uk/>.

$49<\mathrm{http} / / /$ www.consilium.europa.eu/uedocs/cms_data/docs/pressdata/en/ecofin/119888.pdf>

50 The omission seems particularly surprising since real interest rates are now lower in Germany than in any GIPS economy (Figure 6), and public discussions of recent ECB decisions were quite aware of the fact that a rise in interest rates, which would be justified in reference to Germany, might destroy all hopes of recovery in countries such as Spain. 
macroeconomic imbalances that are induced by European monetary impulses that fail to fit the specific conditions of the national economy. Instead, Member States are expected to deal with potential imbalances through the use of their remaining policy instruments - but in doing so, they will be constrained by the rules of the Excessive Deficit Procedure and they will be controlled by the Commission's discretionary interventions under the Excessive Imbalance Procedure.

These conditions contrast unfavourably with those faced by Member States of the former European Monetary System. Though politically committed to pegged exchange rates, their governments had retained autonomous control over all instruments of macroeconomic policy - which they were able to employ with a view to their own economy, its external environment, and their own political priorities and constraints. At the same time, however, the governments of these Member States remained fully accountable to their own constituents for all failures of macroeconomic management.

But the proposed EMU regime also contrasts with conditions faced by member governments of a federal nation state with economically heterogeneous regions. These are deprived of all instruments of macroeconomic management, and they may also suffer from the negative impulses of uniform monetary policies that fail to fit local economic conditions. But if a federal government's monetary policy may be as much part of the problem as is the case in the EMU, its fiscal policies will be very much a part of the solution. Generally, a central government's budget is large; its revenues are based on taxes that have a major impact on economic activity and its expenditures include those programs that are most affected by the rise and decline in economic activity. Hence the national budget raises most of its revenue in high-growth regions, and spends most of it in depressed regions. Quite apart from any intergovernmental transfer programs, therefore, national taxation and national social-policy expenditures will have powerful interregional equalisation effects. Moreover, and perhaps even more importantly, the democratic accountability of central government will be as strong if not stronger than that of lower-level governments - as will be its motivation to employ its policy instruments with a view to the potential political responses of voters in depressed regions.

Compared to both of these regimes, Member States in a reformed Monetary Union will indeed find themselves in the worst of three worlds. Like the provinces or cantons in a federal state, they lose control over the instruments of macroeconomic management, and are likely to suffer from uniform national policies that 
do not fit their regional economy. At the same time, however, the EU budget is miniscule in comparison to the budget of federal states, there are no European taxes and there is no European social policy to alleviate interregional imbalances. Instead, Member States are expected to cope with all economic problems by resorting to their own policy resources. In contrast to members of the former EMS, however, EMU Member States cannot use these policies autonomously, but are subject to the intrusive supervision and potential punishment imposed by supranational authorities - which are not democratically accountable and have no reason to be politically responsive to the citizens affected by their policies.

\section{Is there a Hidden Agenda of EMU Reforms?}

Assuming that the new regime is installed as planned, its economic success would seem to depend on the capacity of the Commission to prevent macroeconomic imbalances by issuing precise policy instructions (named "recommendations") to member-state governments. In order to succeed on these terms, moreover, such instructions would have to fit the economic conditions and trends in seventeen heterogeneous member economies. And they would need to work under the specific conditions and constraints of industrial organisation, labourmarket institutions, administrative capabilities, and political structures in each of these countries. Considering the dismal record of economic forecasts and the lack of empirically grounded theory representing the complex linkages among heterogeneous economic, social and political structures and processes, this seems to imply a staggering research agenda. In this light, the Excessive Imbalance Procedure might well be seen as an extreme manifestation of the "pretense of knowledge" of which Friedrich August von Hayek, in his Nobel lecture of 1974, accused the economic policy makers of the Keynesian era. ${ }^{51}$

Conceivably, however, what the Commission has in mind is something that is intellectually much less demanding. It should be remembered that EMU-friendly economists have always downplayed the fact that the eurozone was not an "optimal currency area". ${ }^{2}$ In the words of the ECB's former Chief Economist, it was sufficient that member economies should respond to asymmetric shocks

"with a high degree of flexibility in the markets for goods and services.... This flexibility is needed above all in the labour market, that is, wages must adjust to changing market conditions ... The more the price system (in the widest sense) bears the bur- 
den of adjustment, the less important is the loss of the national exchange rate and monetary policy instruments, and the greater the benefit of using a single currency..."

And moreover:

"Conditions such as the necessary market flexibility can also be created after entry into monetary union." 53

If this should also be the underlying theory of the present EMU reforms, ${ }^{54}$ it would begin to make sense that many of the requirements imposed by the "Memoranda of Understanding" for Greece and Ireland appear unlikely to reduce public-sector deficits over the short or medium term. Instead, they will impose a wide range of liberalising and market-making "structural reforms" that will weaken union power, privatise public services, liberalise the professions and open public health care and education to commercial service providers.

Obviously, requirements of this type do not have to overcome prohibitive cognitive (empirical and theoretical) difficulties. All they need for guidance are the relatively simple rules-of-thumb of supply-side prescriptions that are derived from the abstract models of neoclassical micro-economics. From this perspective, then, the intended practice of the Excessive Imbalance Procedure would become another instrument for promoting market-liberalism in the European Union. This tendency has characterised European legislation and decisions from the European Court of Justice since the early 1980s - and it is in the process of transforming the "social market economies" of some EU Member States into "liberal market economies". 55

But the reach of "hard" European law is still limited, and the Commission's use of "soft" methods in the "Lisbon Process" have not been very successful in promoting "flexibility" in areas where EU Member States continued to defend their own competences. The "Excessive Imbalance Procedure", however, might now allow the Commission to pursue its liberalising agenda much more widely and effectively. Its "recommendations" merely need to be justified by reference to a

53 Issing, O.: The Birth of the Euro, Cambridge, 2009, 48-50.

$54 \mathrm{I}$ am not here trying to assess their economic plausibility. But one wonders whether greater market flexibility would have prevented the credit financed housing booms in Ireland and Spain (or in the USA)? And would union busting and decentralised wage negotiations have allowed better responses to the German recession than the economically sophisticated bargaining strategy of the powerful $I G$ Metall?

55 Jabko, N.: Playing the Market. A political Strategy for Uniting Europe, 1985-2005, Ithaca, 2006; Scharpf, F.W.: Weshalb die EU nicht zur sozialen Marktwirtschaft werden kann, ZSE 7/3-4 (2009), 419434; Scharpf, F.W.: The Asymmetry of European Integration. Or why the EU Cannot Be a "Social Market Economy", in: Socio-Economic Review 8/2 (2010), 211-250. 
list of indicators of "economic imbalance" - but there is no constraint on the policy changes that may be required. As long as it is alleged that they may somehow have an effect on imbalances, the requirements may specify policy changes in a completely undefined range of national competences - including areas such as labour relations, education or health care that have been explicitly protected against European legislation in successive Treaty versions. And to prevent intergovernmental bargaining from softening the sanctions against non-complying governments, the fines proposed by the Commission would simply be adopted by "reverse qualified-majority" voting in the Council. So it all seems to fit neatly.

\section{Democratic Legitimacy in a Reformed Monetary Union}

Instead of continuing on the slippery slope toward politico-economic conspiracy theories, I will now return to issues of democratic legitimacy. From the perspective of citizens in Greece, Ireland and Portugal, the European and international agencies imposing the "rescue-cum-retrenchment" program are not, themselves, supported by democratic legitimacy. What matters, therefore, is the relationship between citizens and the national governments that are accountable to them. But, as I said in the introduction, accountability has an input-oriented and an outputoriented dimension.

"Output-oriented legitimacy" reflects popular responses to outcomes that may be attributed to the policy output of the government whose performance is at issue. Here, a first general observation is that you cannot require voters to be fair and that governments may be punished for outcomes over which they had no control. A second general point is that electoral responses reflect relative judgments: Three million unemployed in Germany may be a political disaster or a celebrated success depending on the figures of recent years. With that in mind, the "rescuecum-retrenchment" regime presently imposed on GIPS countries can only be considered a disaster of output-oriented legitimacy. Two-digit and still rising rates of unemployment, massive real-wage cuts, and rising social inequality will surely not generate outcome satisfaction. Under such conditions, GIPS governments cannot hope to gain political support by appeals to absolute or relative measures of economic performance.

But that does not, by itself, rule out the possibility of input-oriented legitimation. Democracy is, after all, about collective self-determination rather than wish fulfilment. It is compatible with the need to respect external constraints, and it may also support hard choices and painful sacrifices - provided that these can be 
justified in public discourses as being effective and normatively appropriate in dealing with common problems or achieving the collective purposes of the polity. ${ }^{56}$ At the same time, however, input-oriented democratic legitimacy does presuppose the possibility of politically meaningful choices, and it is not at all compatible with a situation where choices are pre-empted by external domination. ${ }^{57}$

Margaret Thatcher, for example, was able to gain political support for extremely painful retrenchment and structural reforms in Britain after the "Winter of Discontent" of 1979. But in comparison to GIPS governments, Thatcher could appeal to traditional British values to justify sacrifices that she found to be economically necessary and normatively appropriate. ${ }^{58}$ Moreover, all relevant policy parameters were under the control of her (unitary) national government. And most importantly, her program was entirely self-chosen, hammered out over several years in intra-party battles, publicly defended in a successful electoral campaign, and supported by a considerable part of public opinion.

Like Thatcher, the present Greek and Irish governments may, at least for a while, benefit from blaming present hardships on their political predecessors. But they must still struggle with the perception that the "understandings" they had to sign in order to obtain the guarantees of the Financial Stability Fund read less like self-chosen programs than like protocols of an unconditional surrender. Thus, in order to be able to hang on, they may desperately need to negotiate for politically visible European "concessions" and for permission to adopt at least some "nonliberal" policies to alleviate the worst plight of their constituents. If they should fail, and if changes of governments would not seem to make a difference, the legitimacy of the democratic regime itself may be in danger - especially in polities where democratic government is itself a relatively recent achievement.

To a lesser degree, the same problems may also arise in all EMU Member States in consequence of measures required and sanctioned by the Excessive Deficit or Imbalance Procedures. In some countries, of course, market-liberal discourses may be highly persuasive, and governments would have no difficulty in presenting "structural reforms" as autonomous and justifiable national policy choices.

56 Schmidt, V.A.: Does Discourse Matter in the Politics of Welfare State Adjustment?, in: Comparative Political Studies 35/2 (2002), 168-193; Schmidt, V.A.: Democracy in Europe: The EU and National Polities, Oxford, 2006.

57 Pettit, P.: Republicanism: A Theory of Freedom and Government, Oxford, 1997.

58 Schmidt, V.A.: Values and Discourse in the Politics of Adjustment, in: Scharpf, F.W./Schmidt, V.A. (eds.), Welfare and Work in the Open Economy, Vol. 1: From Vulnerability to Competitiveness, Oxford, 2000, 238-242. 
But where the Commission's requirements would violate politically salient interests, preferences and values of national constituencies, compliance may again undermine democratic legitimacy. This is not meant to suggest that we will soon see more banks burning and blood spilt in the streets of Athens, Dublin or Madrid, or of Helsinki and Berlin for that matter. In general, citizens in European countries have less to gain and more to lose from open rebellion than has been the case in Tunisia, Egypt or Libya. And the most vulnerable victims of retrenchment and liberalisation policies may lack the capabilities and resources for effective political action.

But political resignation, alienation and cynicism, combined with growing hostility against "Frankfurt" and "Brussels", and a growing perception of zero-sum conflict between the donors and the recipients of the "rescue-cum-retrenchment" programs, may create the conditions for anti-European political mobilisation from the extremes of the political spectrum. In a worst case scenario, therefore, attempts to save the euro through the policies presently enacted may either fail on their own terms, or undermine democracy in EU Member States as well as endanger European integration itself.

\section{Appendix - Statistical Figures}

Figure 1: Inflation (I)

Figure 2: Labour Costs

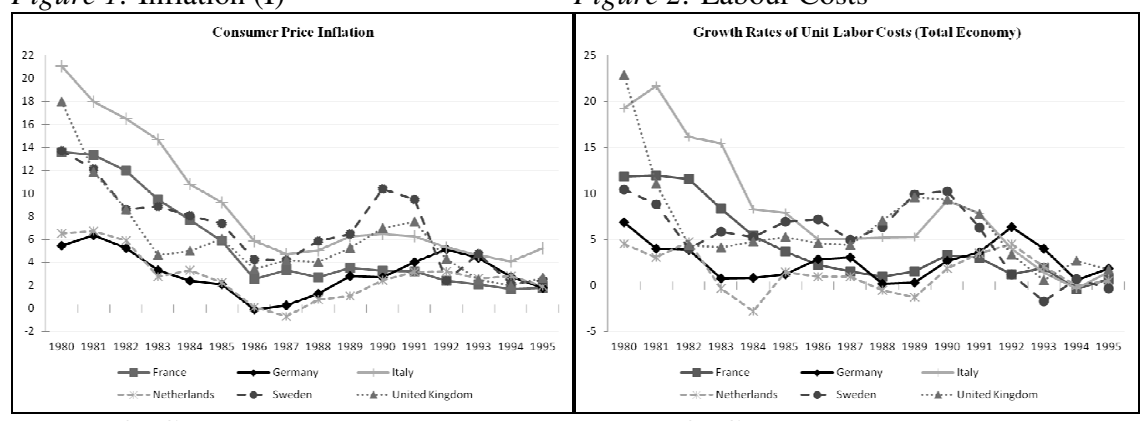

Source: OECD.

Source: OECD. 
Figure 3: Interest Rates on Bonds Figure 4: Inflation (II)

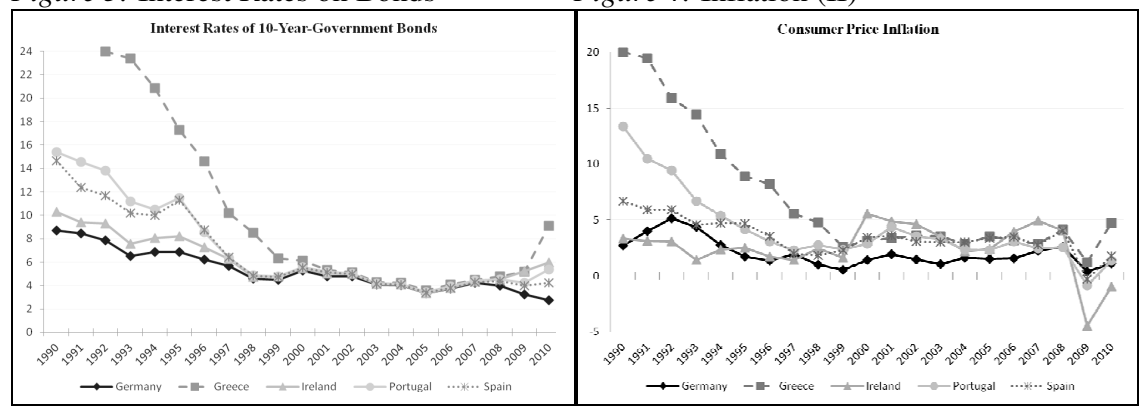

Source: OECD.

Source: OECD.

Figure 5: GDP Growth

Figure 6: Real Interest Rates

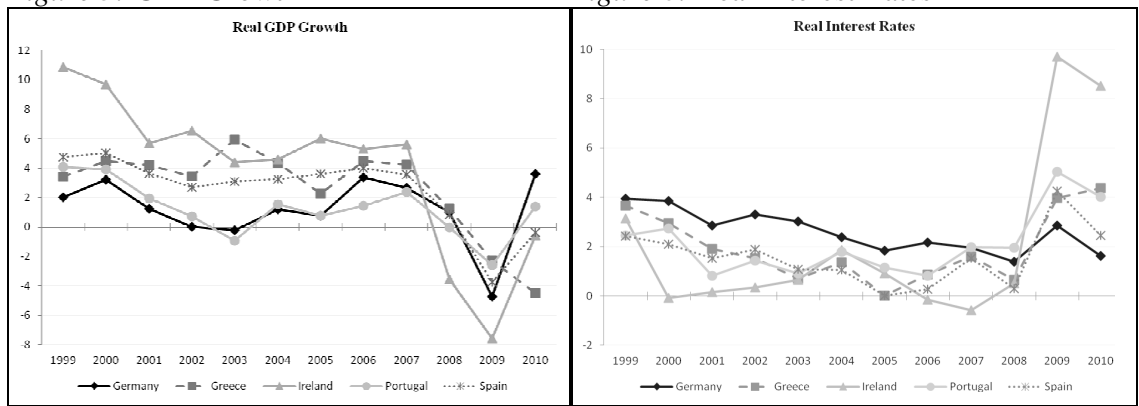

Source: OECD.

Source: Own Calculation, OECD Data.

Figure 7: Unemployment Rates

Figure 8: Real Wages
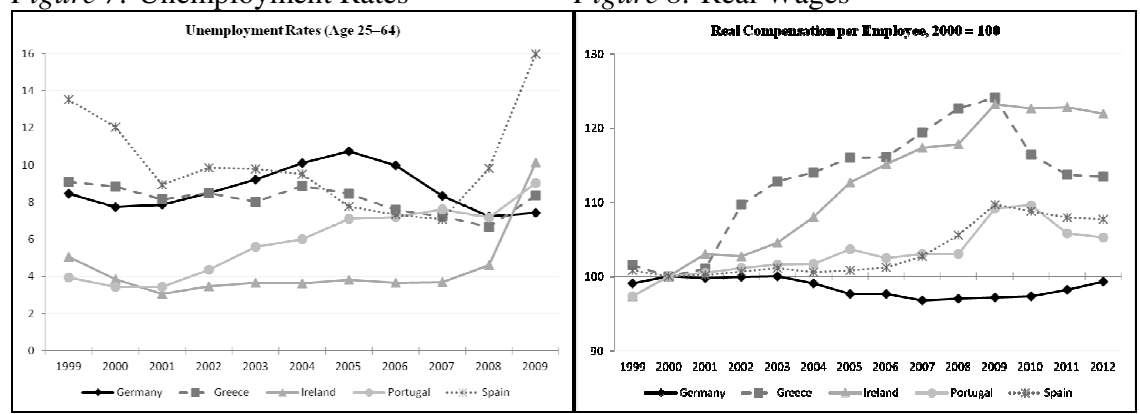

Source: OECD.

Note: Deflator Private Consumption.

Source: Ameco Database. 
Figure 9: Employment Protection Figure 10: Current Account (\% of GDP)
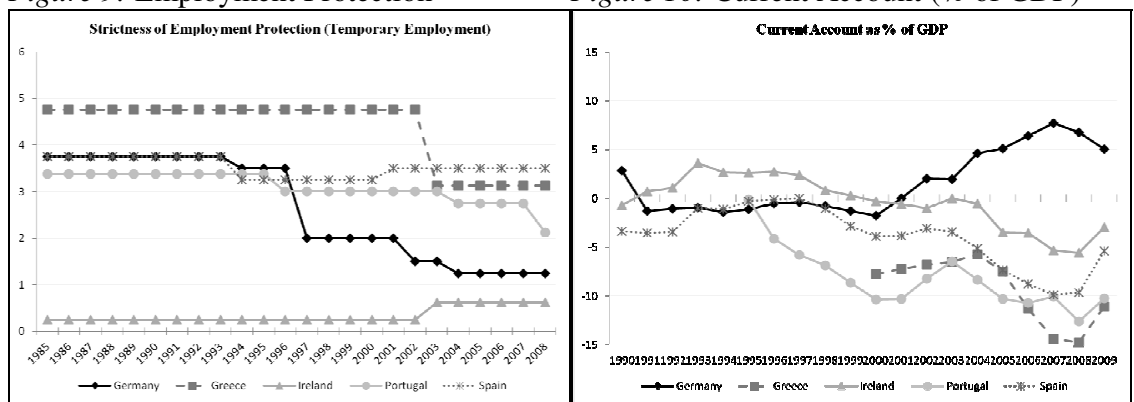

Note: Index Scale 0-6; 6 = strongest

Source: OECD.

protection. Source: OECD.

Figure 11: Employment Rate

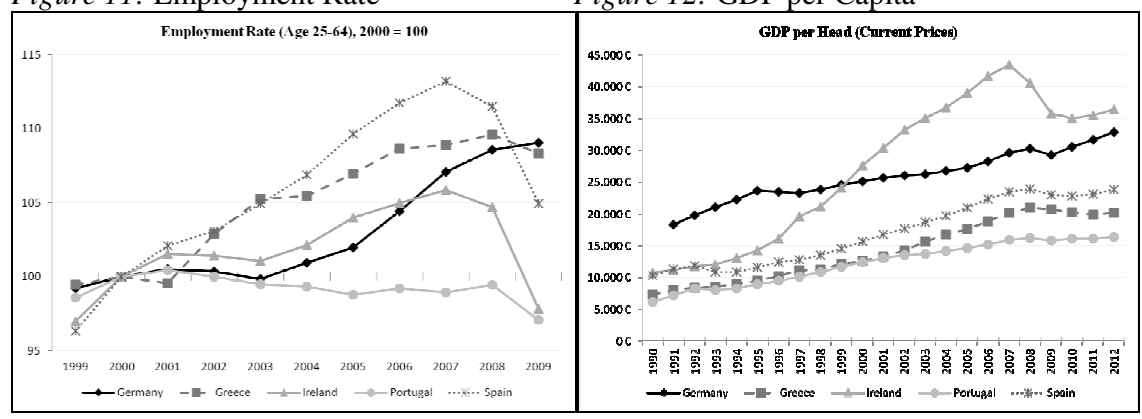

Source: Own Calculation/OECD Data. Source: Ameco Database.

Figure 13: Unit Labour Costs

Figure 14: Capital and Financial Balance

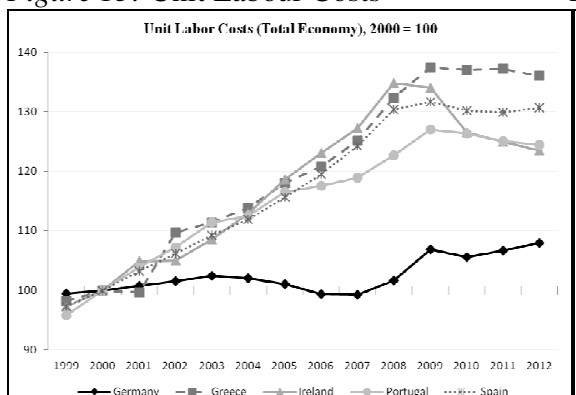

Source: Ameco Database.

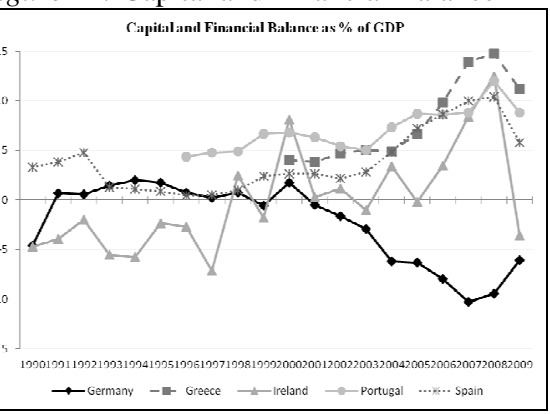

Source: OECD. 
Figure 15: Budget Deficit (\% of GDP) Figure 16: Gross Debt (\% of GDP)

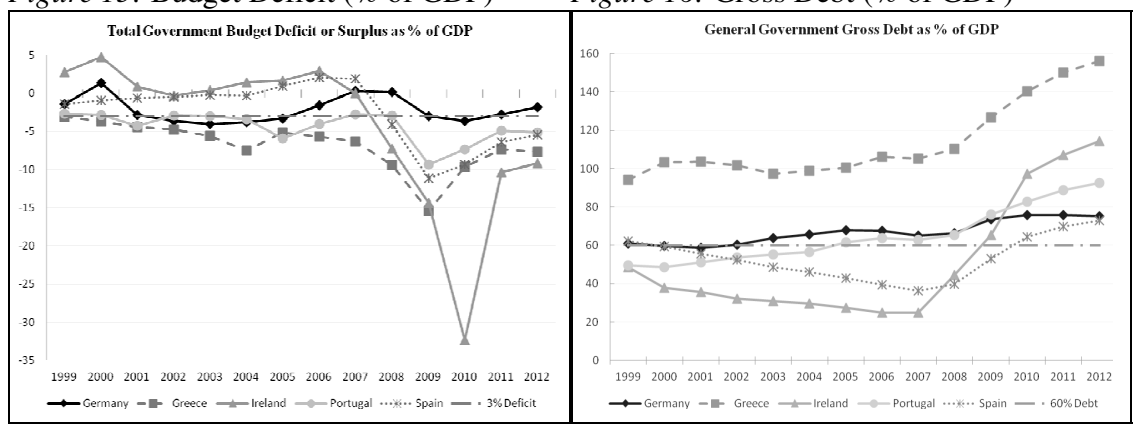

Source: Ameco Database.

Source: Ameco Database.

Figure 17: Real Effective Exchange Rates Figure 18: Interest Rates on Bonds

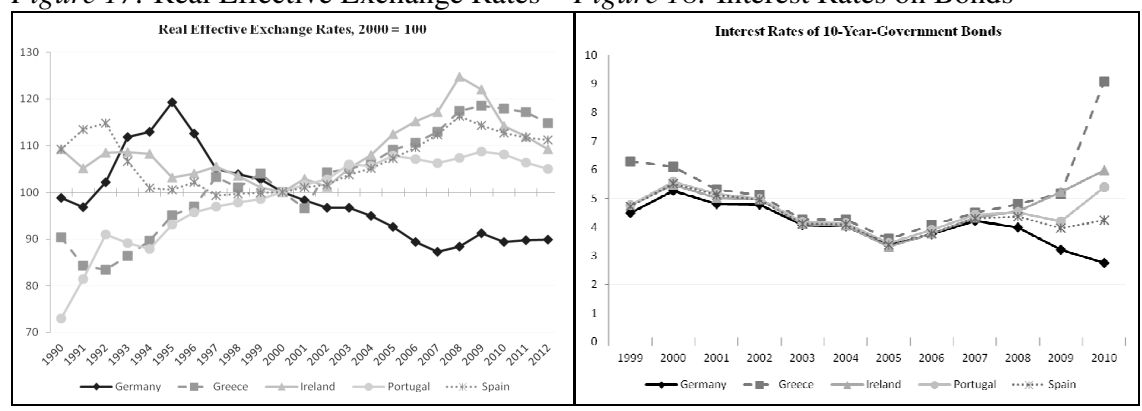

Note: Based on Unit Labour Costs (To- Source: OECD.

tal Economy) Source: Ameco Database.

Figure 19: Monthly Interest Rates

Figure 20: Harmonised Unemployment Rate
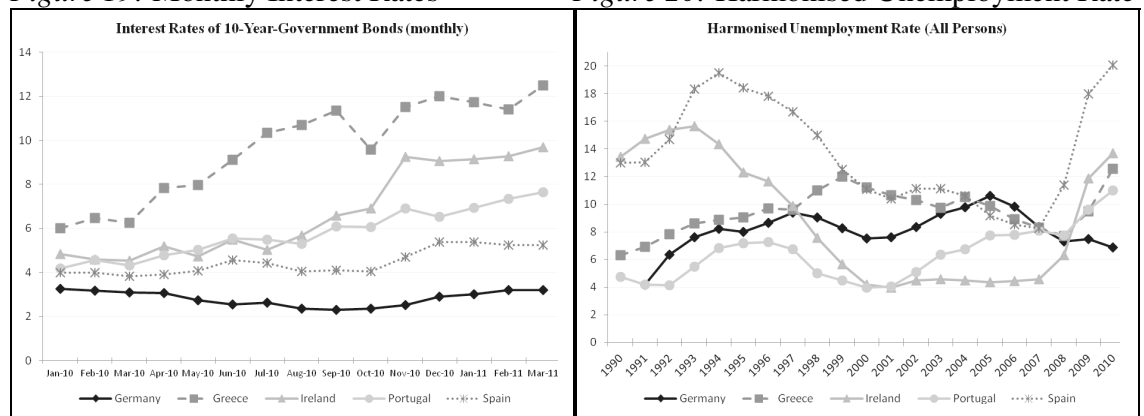

Source: OECD.

Source: OECD. 